\title{
PENERAPAN MODEL WATERFALL PADA PENGEMBANGAN SISTEM INFORMASI REKAM MEDIS KLINIK RAWAT INAP NAJA SHAFANA PURWOKERTO
}

\author{
Eka Rahmawati1; Ragil Wijianto \\ 1,2 Ilmu Komputer \\ STMIK Nusa Mandiri \\ http://nusamandiri.ac.id \\ ekarahmawatiflash@gmail.com; ragil.rgw@nusamandiri.ac.id

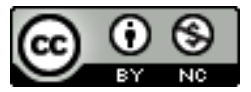 \\ Ciptaan disebarluaskan di bawah Lisensi Creative Commons Atribusi-NonKomersial 4.0 Internasional.
}

\begin{abstract}
Computer is the one of technology that can make people activity easier. To maximize the computer utilization it need a computerization system. Like on Klinik Pratama Rawat Inap Naja Shafana that give health service. The service that given are outpatient, inpatient and emergency unit. Until now, medical records procedure at Klinik Pratama Rawat Inap Naja Shafana still done by hand, one of them is on outpatient procedure. The registration of medical patient data was written on paper that susceptible from damage and data loss. Besides that, the history of medical patient start form anamnesia, diagnose and therapy wrote on paper too. The Medical patient checkup data of inpatient still on a paper. The data have been random archived, so it need long time for searching data and arrange the report. As a health unit that serve general society, Klinik Pratama Rawat Inap Naja Shafana need an information system that can accelerate performance and increase redundancy, data loss and data detriment. The information system also can make archived and data searched easily and can block access from uncompetent people. Therefore, it's necessary to make medical records information system on Klinik Pratama Rawat Inap Naja Shafana. A computerization system besides accelerate performance also can make data reporting easier.
\end{abstract}

Keywords: Information System, Medical Records Information System, Medical Records

Intisari-Komputer merupakan salah satu teknologi yang dapat mempermudah aktivitas manusia. Agar dapat memaksimalkan penggunaan komputer maka perlu dibuat sebuah sistem yang terkomputerisasi. Begitupun pada Klinik Pratama Rawat Inap Naja Shafana yang memberikan pelayanan kesehatan. Pelayanan yang diberikan meliputi rawat jalan, rawat inap dan UGD. Sampai saat ini prosedur rekam medik pada Klinik Pratama Rawat Inap Naja Shafana belum terkkomputerisasi. Salah satunya pada prosedur pendaftaran rawat jalan. Data pasien yang mendaftar dicatat dalam lembaran kertas yang rentan terhadap kerusakan atau hilangnya data. Selain itu riwayat pasien mulai dari anamnesia, diagnosa, dan terapi juga dicatat dalam lembaran kertas. Pencatatan data pemeriksaan pasien rawat inap masih dilakukan dalam lembaran kertas. Data diarsipkan dengan acak, sehingga akan membutuhkan waktu lama dalam pencarian data dan pembuatan laporan. Tempat arsip yang terbuka juga memungkinkan pihak yang tidak berwenang dapat mengakses data. Sebagai unit kesehatan yang melayani masyarakat umum, Klinik Pratama Rawat Inap Naja Shafana membutuhkan sebuah sistem informasi yang dapat mempercepat kinerja dan mengurangi redudansi, hilangnya data dan kerusakan data. Sistem informasi juga dapat mempermudah pengarsipan dan pencarian data serta dapat menghalangi pengaksesan data oleh pihak yang tidak berwenang. Oleh karenanya perlu dibuat sistem informasi rekam medik pada Klinik Pratama Rawat Inap Naja Shafana. Dengan dibuatnya sistem yang terkomputerisasi selain mempercepat kinerja juga akan mempermudah dalam pelaporan data.

Kata Kunci: Perancangan Sistem Informasi, Sistem Informasi Rekam Medis

\section{PENDAHULUAN}

Kesehatan merupakan faktor penting dalam kehidupan manusia. Jika seorang manusia sakit maka aktivitas kesehariannya terganggu. Pentingnya kesehatan bagi manusia mendorong berdirinya tempat pelayanan kesehatan yang 
bergerak sebagai fasilitas publik. Tempat pelayanan kesehatan dapat didirikan oleh pemerintah, swasta maupun perorangan seperti rumah sakit, puskesmas dan klinik kesehatan. Semakin sadarnya masyarakat akan kesehatan maka semakin banyak pula fasilitas pelayanan kesehatan yang didirikian. Untuk menyelaraskan standar pelayanannya maka pemerintah pun membuat standar tersendiri untuk sebuah tempat pelayanan kesehatan yang diatur dalam Peraturan Menteri Kesehatan.

Pesatnya perkembangan teknologi membuat aktifitas manusia dapat dilakukan dengan mudah dan dengan waktu yang singkat. Salah satu teknologi yang membantu aktifitas manusia ialah komputer. Komputer merupakan sebuah alat yang dianggap sebagai barometer kemajuan teknologi, dengan inovasi-inovasinya yang canggih sehingga dapat difungsikan utnuk mempermudah pekerjaan manusia (Kurniadi \& Mulyani, 2015). Dengan adanya komputer maka memicu pula sistem terkomputerisasi. Sistem adalah satu kesatuan komponen yang membentuk interaksi satu sama lain dan untuk mencapai suatu tujuan (Sanjaya,2015). Komputerisasi adalah pemakaian komputer sebagai alat bantu penyelesaian tugas sebagai pengganti penyelesaian pekerjaan manual(Saifuddin \& Handoko, 2018). Sistem terkomputerisasi merupakan sebuah sistem yang melibatkan teknologi dalam pencapaian tujuan sehingga sebuah aktifitas dapat dilaksanakan dengan efektif.

Namun tidak semua aspek dapat mengikuti dengan cepat perkembangan teknologi. Masih banyak instansi khususnya yang bergerak di bidang pelayanan kesehatan masyarakat yang belum menggunakan sistem terkomputerisasi dalam menjalankan aktifitasnya. Seperti pada Klinik Pratama Rawat Inap Naja Shafana yang merupakan salah satu tempat pelayanan kesehatan. Dari pendaftaran pasien hingga pengambilan obat masih menggunakan sistem yang belum terkomputerisasi. Input data operasional harian masih ditulis pada lembaran kertas yang tentu akan semakin bertambah banyak setiap harinya. Data dan informasi pada klinik akan terus bertambah sehingga tidak mudah (Ernawati, 2017) jika pengolahan tidak menggunakan sistem. Kemudian proses pembuatan laporan harus melakukan rekapitulasi tanpa sistem sehingga membutuhkan waktu. Berkas yang terus meumpuk juga rentan terhadap kerusakan dan akan mengalami kesulitan untuk pencarian data pada jangka waktu tertentu.

Pada era teknologi, sistem yang terkomputerisasi diperlukan untuk memberikan kemudahan. Sistem informasi digunakan untuk mengumpulkan, mengolah, dan menyediakan informasi. Selain itu sistem yang terkomputerisasi dapat meningkatkan kinerja dan menghemat waktu. Dari sistem yang sudah ada pada klinik Rawat Inap Naja Shafana, maka diperlukan pengembangan sistem yang mengarah kepada komputerisasi.

Penelitian sebelumnya juga telah membahas mengenai sistem informasi pada instansi penyedia layanan kesehatan. Penelitian dengan judul "Prototipe Peningkatan Pelayanan Rawat Jalan Dengan Pengujian FGD Dan ISO 9126 Pada Klinik Eka Anugerah" yang mengatasi masalah diupayakan dengan menggunakan sistem komputerisasi pada pelayanan pasien(Pujiastuti, 2015). Pada Analisis dan Perancangan Sistem Informasi Rekam Medis Pada Puskesmas Simpang Timbangan Indralaya disebutkan bahwa sistem informasi rekam medis yang terintegrasi dibutuhkan pada puskesmas Simpang Timbangan Indralaya sehingga dapat memperbaiki sistem yang lama(Sihotang, 2015). Penggunaan sistem terkomputerisasi untuk instansi penyedia layanan kesehatan sangat penting untuk meningkatkan kinerja.

\section{BAHAN DAN METODE}

Gambar1 menunjukan metode penelitian yang diusulkan. Metode dimulai dengan pengumpulan data. Data Collection dilakukan dengan observation, study literature, dan interview. Observation dilakukan dengan melakukan pengamatan terhadap kegiatan yang berkaitan dengan rekam medis rawat jalan dan rawat inap. Observasi dibutuhkan untuk mendapatkan datadata yang diperlukan seperti data tentang Klinik Pratama Rawat Inap Naja Shafana secara umum, data dokter, data pasien, data obat dan data lain yang berkaitan dengan rekam medis.

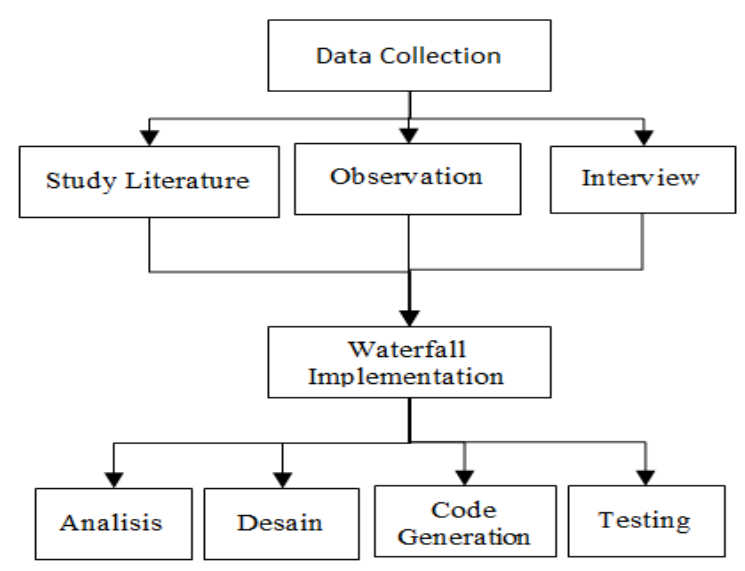

Sumber: (Rahmawati, 2017)

Gambar1. Metode Penelitian 
Wawancara dilakukan untuk mendapatkan informasi yang akurat. Wawancara dilakukan kepada paramadis klinik mengenai sistem berjalan rekam medis. Selain itu, wawancara juga dilakukan kepada pasien yang berkunjung mengenai pelayanan kesehatan pada Klinik Pratama Rawat Inap Naja Shafana.

Selain melakukan observasi dan wawancara, studi pustaka juga diperlukan untuk membantu menganalisa prosedur pada Klinik Pratama Rawat Inap Naja Shafana. Studi Pustaka dilakukan dengan mempelajari beberapa buku, jurnal dan literature yang sesuai atau relevan dengan topik penelitian.

Model pengembangan sistem yang digunakan adalah model air terjun (waterfall). Model SDLC air terjun (waterfall) sering juga disebut model sekuensial linier atau alur hidup klasik. Model air terjun menyediakan pendekatan alur hidup perangkat lunak secara sekuensial atau terurut dimulai dari analisis, desain, pengodean, pengujian, dan tahap pendukung (support)(Hidayat, Marlina, \& Utami, 2017).

\section{HASIL DAN PEMBAHASAN}

A. Analisis

Penggunaan sistem terkomputerisasi pada sebuah instansi bertujuan untuk menambah kelancaran dalam proses pengolahan data. Selain itu sistem terkomputerisasi dapat mengurangi permasalahan yang berkaitan dengan hilang atau rusaknya data dan meminimalisir kesalahan dalam pengolahan data. Berikut spesifikasi kebutuhan (system requirement) dari sistem informasi rekam medis:

A1. Petugas administrasi dapat mengelola data pasien.

A2. Kepala Klinik dapat mengelola data paramedis. A3. Kepala Klinik, admin rawat jalan dapat mengelola data pelayanan.

A4. Apoteker dapat mengelola data obat.

A5. Kepala Klinik, admin rawat jalan dapat mengelola data rumahsakit rujukan.

A6. Kepala Klinik, admin rawat jalan dapat mengelola data poli.

A7. Kepala Klinik, admin rawat inap dapat mengelola data kamar.

A8. Kepala Klinik, admin rawat inap dapat mengelola data disposable.

A9. Kepala Klinik, admin rawat inap dapat mengelola data tindakan.

A10. Kepala Klinik, admin IGD dapat mengelola data IGD.

A11. Petugas Administrasi dapat mengelola data pendaftaran.
A12. Admin rawat jalan, dokter, perawat dapat mengelola data rawat jalan.

A13. Admin rawat inap dapat mengelola data rawat inap.

A14. Petugas administrasi dapat mengelola kartu kontrol.

A15. Dokter, admin rawat jalan, admin rawat inap dapat mengelola surat rujukan.

A16. Dokter, admin rawat jalan, admin rawat inap dapat mengelola surat keterangan sakit.

A17. Dokter, admin rawat jalan dapat mengelola surat keterangan sehat.

A18. Kepala Klinik dapat megelola laporan data master.

A19. Kepala Klinik dapat mengelola laporan data transaksi.

A20. Doker, bidan dapat mengelola data KIA.

A21. Dokter dapat mengelola data pemeriksaan gigi.

A22. Dokter, bidan dapat mengelola data bersalin.

B. Desain

Desain dilakukan dengan menggunakan diagram activity diagram, use case diagram, ERD, LRS, Component Diagram, dan Deployment Diagram.

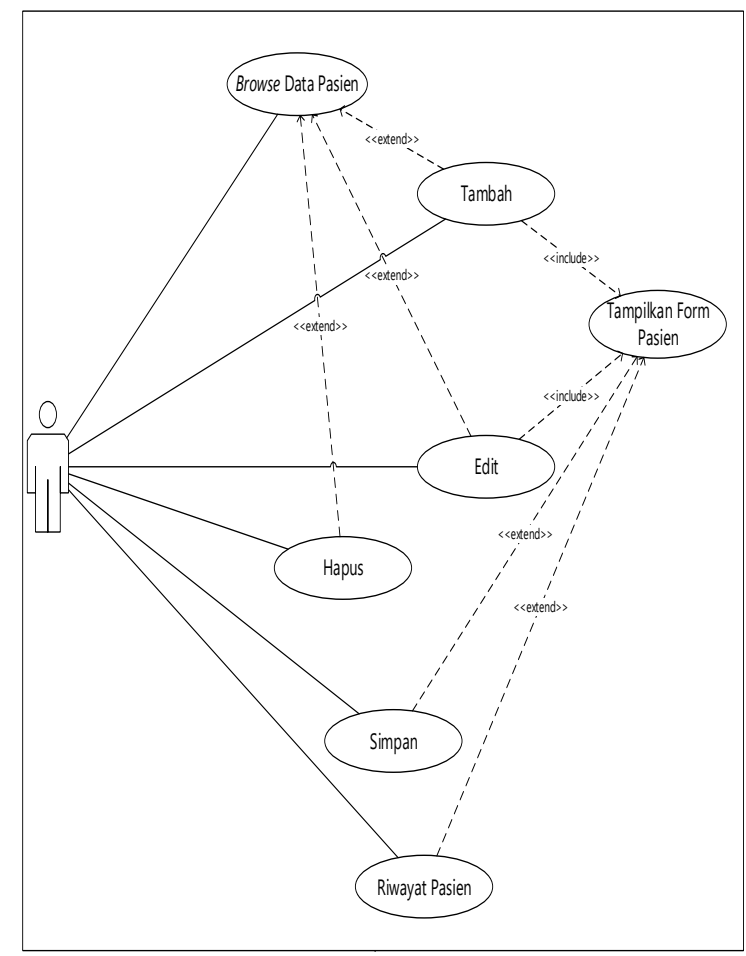

Sumber: (Rahmawati, 2017)

Gambar 2. Use Case Diagram Mengelola Data Pasien

Gambar2 menunjukan seluruh aktivitas yang dilakukan pada klinik. Keseluruhan aktivitas 
yang ada kemudian digambarkan pada use case diagram.

Tabel 1. Deskripsi Use Case Diagram Mengelola Data Pasien

\begin{tabular}{|c|c|}
\hline Usecase Name & Mengelola Data Pasien \\
\hline Requirements & A1 \\
\hline Goal & $\begin{array}{l}\text { Admin dapat menambah, } \\
\text { mengedit dan menghapus } \\
\text { data pasien. } \\
\text { Admin dapat mengetahui } \\
\text { riwayat penyakit pasien. }\end{array}$ \\
\hline Pre-conditions & Admin telah login \\
\hline Post-conditions & $\begin{array}{l}\text { Data pasien tersimpan, ter- } \\
\text { update, dan terhapus }\end{array}$ \\
\hline Failed end conditions & $\begin{array}{l}\text { Gagal menyimpan, meng- } \\
\text { update, dan menghapus }\end{array}$ \\
\hline Primary Actors & Administrator \\
\hline Main Flow / Basic Path & $\begin{array}{l}\text { 1. Admin melihat data } \\
\text { 2. Admin menambah data } \\
\text { pasien } \\
\text { 3. Admin menyimpan data } \\
\text { pasien }\end{array}$ \\
\hline Invariant $A$ & $\begin{array}{l}\text { 2a. Admin mengedit data } \\
\text { pasien }\end{array}$ \\
\hline Invariant $B$ & $\begin{array}{l}\text { 2b. Admin menghapus data } \\
\text { pasien }\end{array}$ \\
\hline
\end{tabular}

Sumber: Rahmawati (2017)

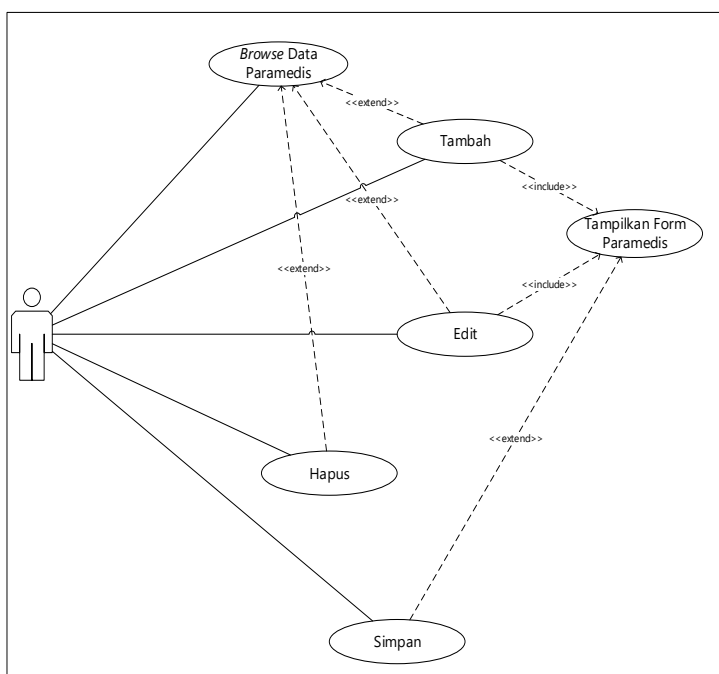

Sumber: (Rahmawati, 2017)

Gambar 3. Detail Use Case Diagram Mengelola Data Paramedis

Tabel 2 Deskripsi Use Case Diagram Mengelola Data Paramedis

\begin{tabular}{ll}
\hline Usecase Name & Mengelola Data Paramedis \\
\hline Requirements & A2 \\
\hline Goal & $\begin{array}{l}\text { Admin dapat menambah, } \\
\text { mengedit dan menghapus } \\
\text { data Paramedis }\end{array}$ \\
\hline Pre-conditions & Admin telah login \\
\hline Post-conditions & $\begin{array}{l}\text { Data Paramedis tersimpan, } \\
\text { ter-update, dan terhapus }\end{array}$ \\
\hline Failed end conditions & $\begin{array}{l}\text { Gagal menyimpan, meng- } \\
\text { update, dan menghapus }\end{array}$ \\
\hline Primary Actors & Administrator \\
\hline
\end{tabular}

\begin{tabular}{ll}
\hline Main Flow / Basic Path & 1. $\begin{array}{l}\text { Admin melihat data } \\
\text { Paramedis } \\
\text { Admin menambah data } \\
\text { Paramedis } \\
\text { Admin menyimpan data } \\
\text { Paramedis }\end{array}$ \\
\hline Invariant $A$ & $\begin{array}{l}\text { 2a. Admin mengedit data } \\
\text { Paramedis }\end{array}$ \\
\hline Invariant B & $\begin{array}{l}\text { 2b. Admin menghapus data } \\
\text { Paramedis }\end{array}$ \\
\hline
\end{tabular}

Sumber: Rahmawati (2017)

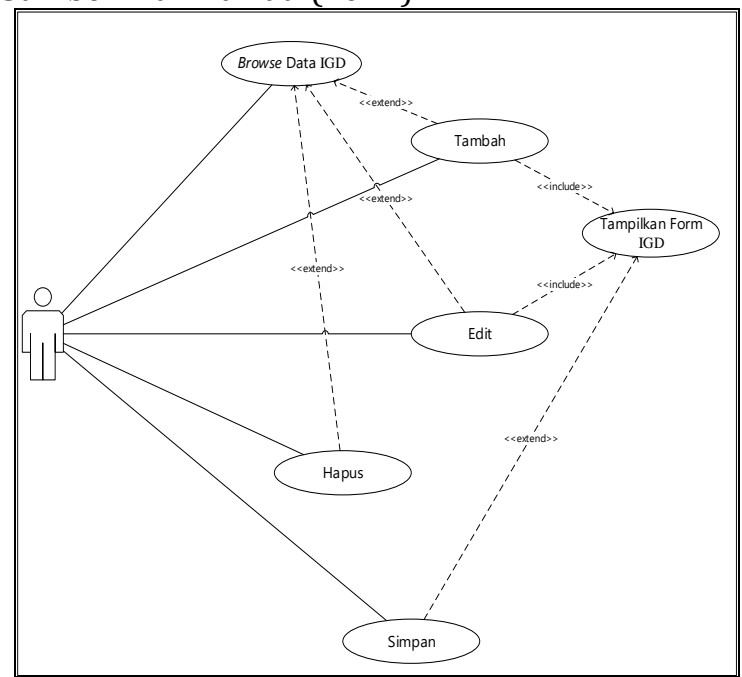

Sumber: (Rahmawati, 2017)

Gambar 4. Detail Use Case Diagram Mengelola Data IGD

Tabel 3. Deskripsi Use Case Diagram Mengelola Data IGD

\begin{tabular}{ll}
\hline Usecase Name & Mengelola Data IGD \\
\hline Requirements & A10 \\
\hline Goal & $\begin{array}{l}\text { Admin dapat menambah, } \\
\text { mengedit dan menghapus } \\
\text { data IGD }\end{array}$ \\
\hline Pre-conditions & Admin telah login \\
\hline Post-conditions & $\begin{array}{l}\text { Data IGD tersimpan, ter- } \\
\text { update, dan terhapus }\end{array}$ \\
\hline Failed end conditions & $\begin{array}{l}\text { Gagal menyimpan, meng- } \\
\text { update, dan menghapus }\end{array}$ \\
\hline Primary Actors & Administrator \\
\hline Main Flow / Basic Path & 1. Admin melihat data \\
& \multicolumn{1}{c}{ IGD Admin menambah } \\
& data IGD \\
& 3. Admin menyimpan \\
& data IGD \\
\hline Invariant $A$ & 2a. Admin mengedit data \\
\hline Invariant B & $\begin{array}{l}\text { 2b. Admin menghapus } \\
\text { data IGD }\end{array}$ \\
\hline
\end{tabular}

Sumber: Rahmawati (2017) 


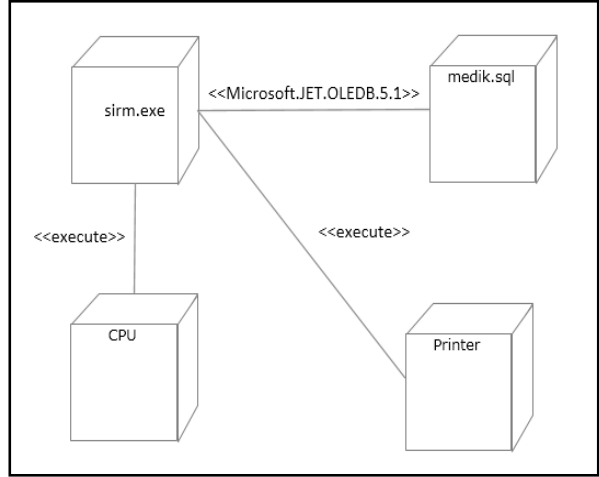

Sumber: (Rahmawati, 2017)

Gambar 5. Deployment Diagram

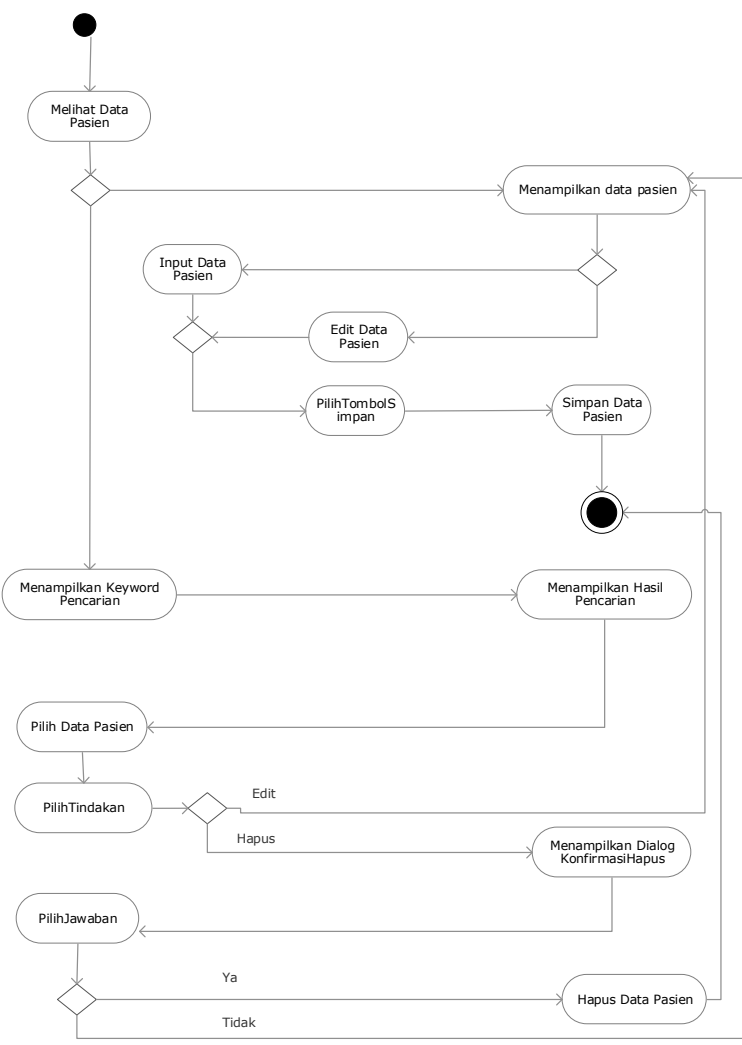

Sumber: (Rahmawati, 2017)

Gambar 6. Activity Diagram Mengelola Data Pasien

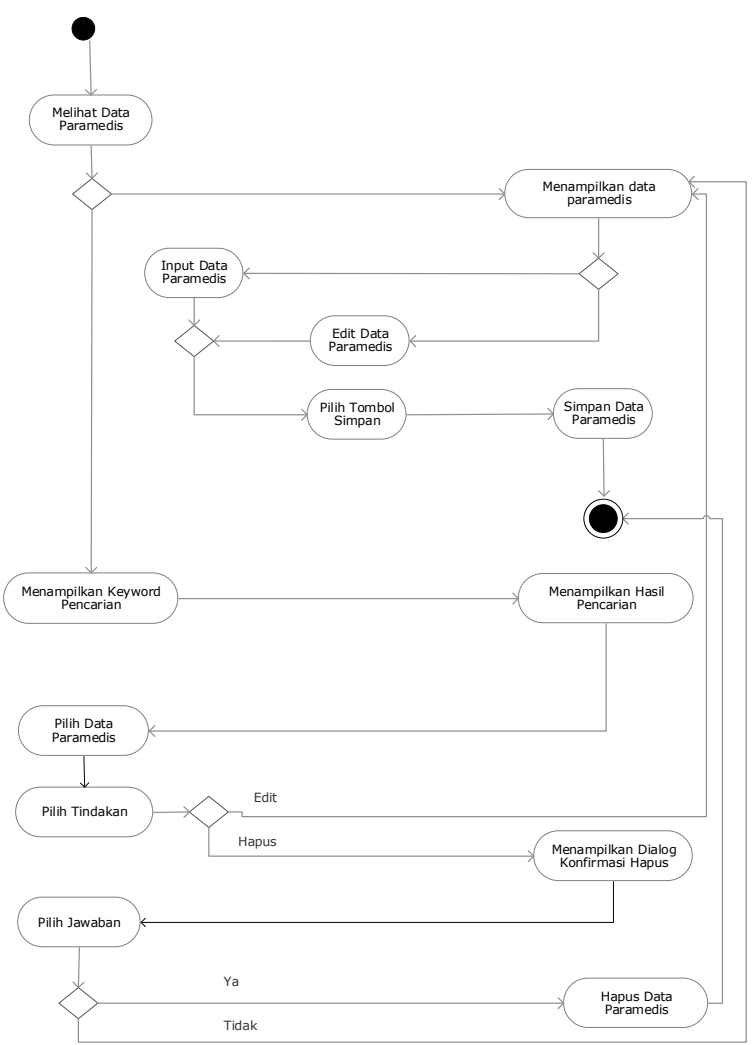

Sumber: Rahmawati (2017)

Gambar 7. Activity Diagram Mengelola Data Paramedis

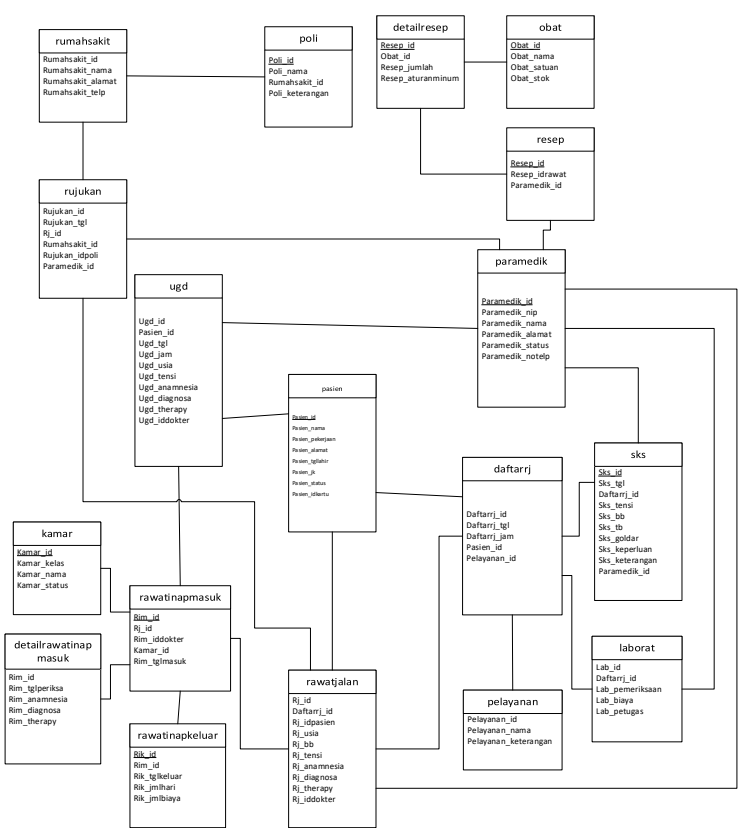

Sumber: (Rahmawati, 2017)

Gambar 8.Logical Record Structure Sistem Rekam Medis

LRS menggambarkan adanya relasi antar tabel akibat adanya relasi antara himpunan entitas. Setiap tabel yang terdapat pada database memiliki 
keterkaitan untuk membangun sistem terkomputerisasi.

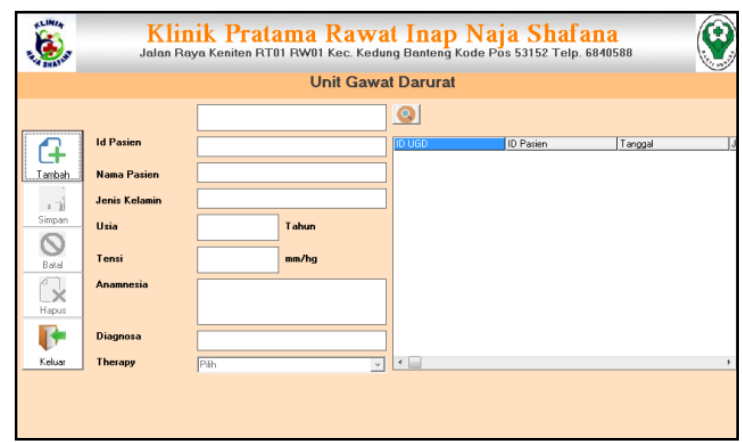

Sumber: (Rahmawati, 2017)

Gambar 9.Form UGD

Gambar 9 merupakan tampilan dari form UGD. Form tersebut dapat diakses oleh dokter umum atau admin UGD saat ada pasien masuk ke UGD. Form juga difungsikan untuk input data pasien yang masuk beserta tindakan yang dilakukan terhadap pasien.

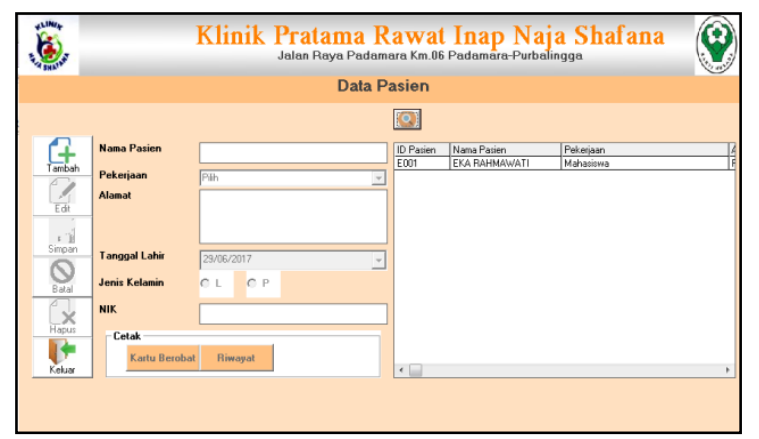

Sumber: (Rahmawati, 2017)

Gambar 10.Form Data Pasien

Gambar 10 merupakan tampilan dari form data pasien. Form tersebut berfungsi untuk menambahkan data pasien baru. Form dapat diakses oleh bagian administrasi.

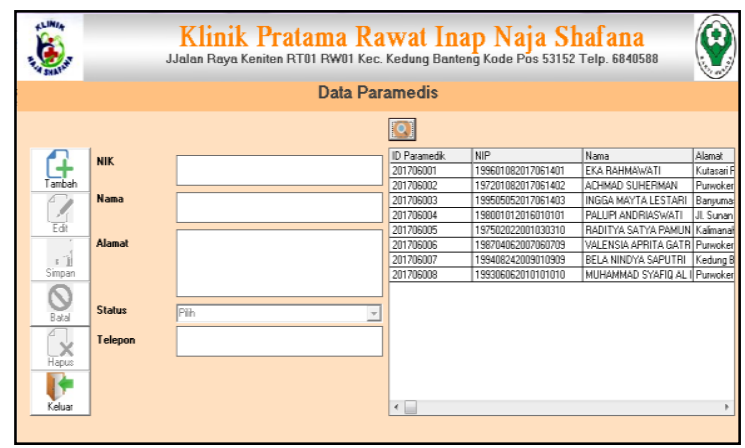

Sumber: (Rahmawati, 2017)

Gambar 11.Form Data Paramedis
Gambar 11 adalah form paramedis. Form ini digunakan untuk input data seluruh paramedis yang ada. Form dapat diakses oleh Kepala Klinik.

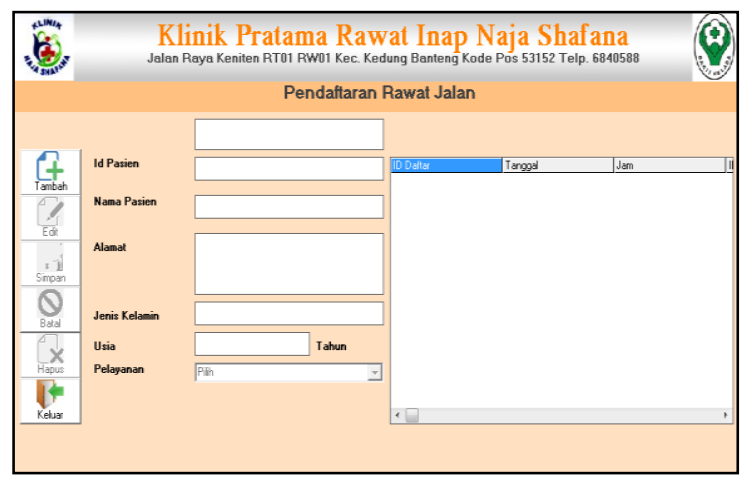

Sumber: (Rahmawati, 2017)

Gambar 12.Form Pendaftaran Rawat Jalan

Gambar 12 menunjukan form pendaftaran rawat jalan. Form tersebut dapat diakses oleh admin rawat jalan untuk input data pasien yang akan berobat di klinik.

\section{Code}

Private Sub no_otomatis()

Dim judul, x As String

Dim no As Integer

Call koneksinya

judul = "DFT"

ttgl = Format(Date, "DD/MM/YYYY")

thariini = Format(Date, "ddmmyy")

rsdaftarrj.Open "select*from daftarrj where mid(daftarrj_id,4,6)='" \& thariini \& "' order by daftarrj_id asc", konek

Text1. Text $=$ thariini

With rsdaftarrj

If .EOF Then

tid = judul + Format(Date, "ddmmyy") + "001"

Else

.MoveLast

$\mathrm{x}=$ Mid(!daftarrj_id, 10, 3)

no $=\mathrm{x}+1$

tid $=$ judul + Format(Date, "ddmmyy") +

Right("000" \& no, 3)

End If

End With

End Sub

Private Sub tidpasien_KeyPress(KeyAscii As Integer)

KeyAscii = Asc(UCase $($ Chr $($ KeyAscii $))$

Call koneksinya

If KeyAscii = 13 Then

rspasien.Open "SELECT * FROM pasien where pasien_id ='" \& tidpasien \& "'", konek

With rspasien

If .BOF And .EOF Then

MsgBox tidpasien + " Tidak Ada ", vbInformation,

"PENCARIAN"

tidpasien.SetFocus 
Else

'rsdaftarrj.Open "select*from daftarrj where daftarrj_idpasien='" \& tidpasien \& "'", konek

'If Not rsdaftarrj.BOF And rsdaftarrj.EOF Then

'If MsgBox("Pasien sudah mendaftar hari ini, tetap

tambahkan pasien?", vbQuestion + vbOKCancel) = vbOK Then

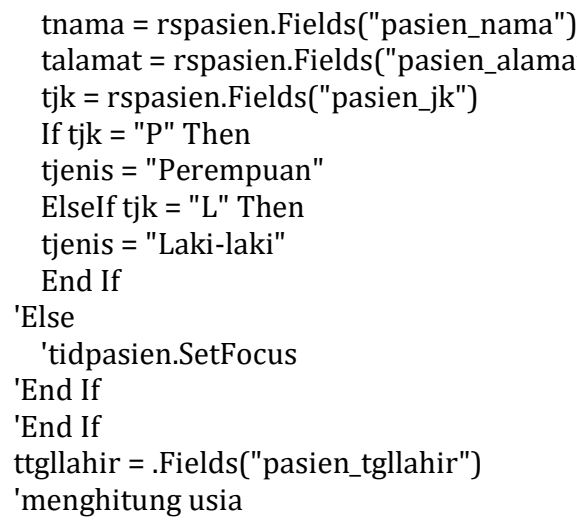

\section{Testing}

Setelah kode diimplementasikan, metode black box testing dilakukan untuk mengevaluasi program. Tujuan dilakukan blackbox testing adalah untuk mendeteksi adanya kesalahan atau kegagalan pada sistem informasi rekam medis.

Tabel 4 Hasil Pengujian Black Box Testing Form Pendaftaran

\begin{tabular}{|c|c|c|c|c|c|}
\hline No & $\begin{array}{c}\text { Skema } \\
\text { Pengujian }\end{array}$ & Test Case & $\begin{array}{l}\text { Hasil Yang } \\
\text { Diharapkan }\end{array}$ & $\begin{array}{c}\text { Hasil } \\
\text { Pengujian }\end{array}$ & $\begin{array}{c}\text { Kesimpul } \\
\text { an }\end{array}$ \\
\hline 1 & \begin{tabular}{l}
\multicolumn{2}{l}{ Mengosongan } \\
semua isian \\
data lalu \\
langsung klik \\
tombol simpan
\end{tabular} & $\begin{array}{l}\text { Id Pasien: } \\
\text { kosong } \\
\text { Pelayanan: } \\
\text { kosong }\end{array}$ & $\begin{array}{l}\text { Sistem akan } \\
\text { menolak } \\
\text { akses simpan } \\
\text { dan } \\
\text { menampilkan } \\
\text { pesan "Id } \\
\text { Pasien Tidak } \\
\text { Boleh } \\
\text { Kosong" }\end{array}$ & $\begin{array}{c}\text { Sesuai } \\
\text { Harapan }\end{array}$ & Valid \\
\hline 2 & $\begin{array}{l}\text { Hanya mengisi } \\
\text { data idpasien } \\
\text { dan } \\
\text { mengosongkan } \\
\text { data pelayanan } \\
\text { lalu langsung } \\
\text { mengklik } \\
\text { tombol simpan }\end{array}$ & $\begin{array}{l}\text { Id Pasien: } \\
\text { E001 } \\
\text { Pelayanan: } \\
\text { kosong }\end{array}$ & $\begin{array}{l}\text { Sistem akan } \\
\text { menolak } \\
\text { akses simpan } \\
\text { dan } \\
\text { menampilkan } \\
\text { pesan } \\
\text { "Pelayanan } \\
\text { Tidak Boleh } \\
\text { Kosong" }\end{array}$ & $\begin{array}{l}\text { Sesuai } \\
\text { Harapan }\end{array}$ & Valid \\
\hline 3 & $\begin{array}{l}\text { Menginputkan } \\
\text { data yang } \\
\text { benar lalu } \\
\text { mengklik } \\
\text { tombol simpan }\end{array}$ & $\begin{array}{l}\text { Id Pasien: } \\
\text { E001 } \\
\text { (benar) } \\
\text { Pelayanan: } \\
\text { Poli } \\
\text { Umum } \\
\text { (benar) }\end{array}$ & $\begin{array}{l}\text { Sistem } \\
\text { menerima } \\
\text { akses simpan } \\
\text { dan data } \\
\text { berhasil } \\
\text { disimpan }\end{array}$ & $\begin{array}{c}\text { Sesuai } \\
\text { Harapan }\end{array}$ & Valid \\
\hline
\end{tabular}

Sumber: (Rahmawati, 2017)

Tabel 4 menunjukan bahwa pada form login tidak ada kesalahan fungsi dari sistem informasi. Uji coba yang dilakukan menunjukan bahwa setiap form yang ada sudah sesuai dengan kebutuhan pengguna.

\section{KESIMPULAN}

Prosedur rekam medis pada Klinik Naja Shafana belum terkomputerisasi. Penggunaan program rekam medis dapat mempercepat proses pengolahan data. Pengolahan data meliputi proses input data, penyimpanan data, pencarian data, pengubahan data dan penghapusan data. Pencetakan kartu kontrol dan riwayat penyakit pasien dapat dilakukan dengan mudah dan mengurangi resiko kesalahan penulisan. Untuk mendapatkan daftar riwayat penyakit tidak perlu mencari di dalam arsip. 
Penggunaan sistem yang terkomputerisasi dapat mengurangi redudansi dan kesalahan pencatatan. Laporan transaksi maupun file master dapat diperoleh dengan mudah dan cepat serta dicetak kapan saja. Data dapat diarsipkan dalam bentuk soft file dan cetak, sehingga mengurangi resiko hilang atau rusaknya data. Pengarsipan dalam bentuk soft file juga mempermudah pengguna dalam mencari data.

Evaluasi lanjutan diperlukan untuk mengetahui kinerja sistem secara keseluruhan dengan menggunakan kuisioner dari pengguna sistem informasi. Pengembangan software juga diperlukan agar dapat membantu meningkatkan kinerja sistem sesuai dengan kebutuhan. Pelatihan kepada seluruh pengguna ekosistem diperlukan untuk penerapan sistem baru.

\section{REFERENSI}

Ernawati, S. (2017). IMPLEMENTASI MODEL WATERFALL PADA SISTEM INFORMASI PEREKAMAN DATA MEDIS PASIEN RAWAT JALAN (STUDI KASUS : UPTD PUSKESMAS SEMPLAK BOGOR). Jurnal Techno Nusa Mandiri, 14(2), 125-130. https://doi.org/10.33480/TECHNO.V14I2.5 29

Hidayat, R., Marlina, S., \& Utami, L. D. (2017). Perancangan Sistem Informasi Penjualan Barang Handmade Berbasis Website Dengan Metode Waterfall, 175-183.

Kurniadi, D., \& Mulyani, A. (2015). Prototipe perangkat lunak sistem kendali peralatan elektronik berbasis komputer. Jurnal Wawasan Ilmiah.

Pujiastuti, E. (2015). Prototipe Peningkatan Pelayanan Rawat Jalan Dengan Pengujian FGD Dan ISO 9126 Pada Klinik Eka Anugerah. IJSE-Indonesian Journal on Software Engineering, 1(1), 62-69.

Saifuddin, \& Handoko. (2018). PEMANFAATAN DATABASE MYSQL UNTUK PROSES KOMPUTERISASI PEMINJAMAN DAN PENEMBALIAN ALAT LABORATORIUM DI SMK BINAWIYATA SRAGEN. Jurnal IT CIDA, 2(1), 67-73.

Sihotang, F. P. (2015). Analisis dan Perancangan Sistem Informasi Rekam Medis Pada Puskesmas Simpang Timbangan Indralaya, 1(2), 149-163. 